\title{
Kognitiivisten palvelujen ja kognitiivisten prosessien kohdentaminen
}

\author{
Virpi Hotti, Henna Lauronen
}

School of Computing, University of Eastern Finland, Kuopio, Finland

Virpi Hotti, School of Computing, University of Eastern Finland, FI-70211, Kuopio, FINLAND. Email: virpi.hotti@uef.fi

\section{Tiivistelmä}

Kognitiivinen aikakausi lisää ihmisten aivokuntoa eli kognitiivista suorituskykyä sekä kognitiivisten palvelujen että niitä hyödyntävien sovellusten avulla. Kognitiivisten palvelujen kehittäminen kuuluu kognitiiviseen laskentaan, jossa pyritään algoritmien avulla matkimaan aivomekanismeja. Jotta aivomekanismeja opitaan matkimaan, on tunnettava kognitiiviset toiminnallisuudet. Tässä artikkelissa kognitiiviset palvelut (IBM:Itä neljä ja Microsoftilta seitsemän) kohdennetaan kognitiivisiin prosesseihin 14 kohdentamisäännön avulla. Koska kohdentaminen edellytti kognitiivisten palvelujen tuotosten yksityiskohtaista tarkastelua, niin myös tuotosten hyödyntämiseen muodostettiin kohdentamismalli.

Avainsanat: algoritmit, kyky, kognitiivinen toiminto

\begin{abstract}
The cognitive era increases the people's brain condition, in other words cognitive ability with the cognitive services and applications. The developing of the cognitive services belongs to the cognitive computing where an attempt is to mimic brain mechanisms by the algorithms. Therefore, the cognitive functions must be known. In this paper, the cognitive services (four from IBM and seven from Microsoft) are mapped into the cognitive processes within 14 mapping rules. Finally, the mapping model of the detailed outcomes of the cognitive services was constructed.
\end{abstract}

Keywords: algorithms, ability, cognitive function

\section{Johdanto}

Ihmisen kognitiivisella suorituskyvyllä eli aivokunnolla "tarkoitetaan sitä, kuinka hyvin yksilö havaitsee, muistaa, tarkkailee ja valitsee tärkeitä asioita epäoleellisten asioiden joukosta, ja myös sitä, kuinka hyvin hän pystyy suunnittelemaan toimintaansa ja valitsemaan tavoitteensa muuttuvissa toimintaympäristöissä" [1]. Kun tarkastellaan asioita, jotka liittyvät kognitiiviseen suorituskykyyn, niin voimme tarkastella kognitiota aivojen ja geenien näkökulmasta eli tarkasteltavaksi otetaan otsalohkot (frontal lobes) ja hippokampus sekä geeneistä DRD4 ja MAOA (Kuva 1). Baddeley et al. (2015) ajattelevat, että kognitioon kuuluu tarkkaavaisuuden (attention) lisäksi lyhytkestoinen työmuisti ja pitkäkestoinen muisti [2]. 


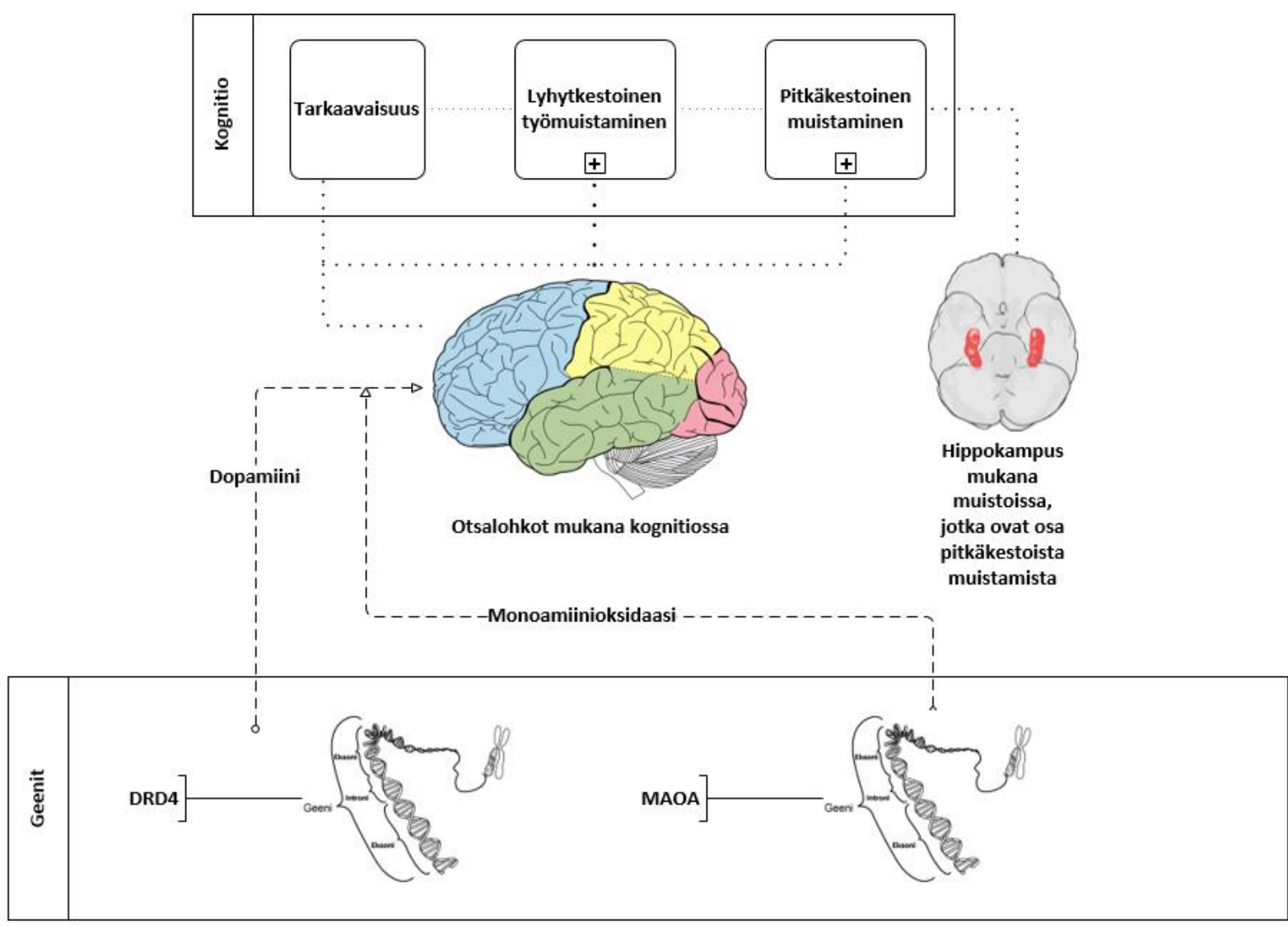

Kuva 1. Kognitio aivojen ja geenien kehyksessä (mukaillen [2, s. 24] ja kuvassa on käytetty julkiseksi luokiteltuja kuvia aivojen lohkoista ${ }^{1}$ ja hippokampuksesta ${ }^{2}$ sekä geenistä ${ }^{3}$ ). Aivojen ja geenien tarkastelu on kiehtovaa. Esimerkiksi dopamiinireseptorigeeni (DRD4) säätelee dopamiinin aineenvaihduntaa ja se liittyy moneen käyttäytymisfenotyyppiin ${ }^{4}$ kuten matkustushalukkuuteen ${ }^{5}$, seksuaaliseen aktiivisuuteen ${ }^{6}$ ja syömishäiriöihin ${ }^{7}$. Monoamiinioksidaasi A (MAOA) -geeni liittyy muun muassa epäsosiaaliseen käyttäytymiseen ${ }^{8}$ ja vaikuttaa muun muassa keskushermoston välittäjäaineen dopamiinin hajottamiseen aivoissa ${ }^{9}$. Otsalohkojen (frontal lobes) korostaminen on perusteltua, sillä ne osallistuvat monimutkaisiin tehtäviin kuten "arvosteluun, ymmärrykseen, tulevaisuuden suunnitteluun, uteliaisuuteen, abstraktiin ajatteluun ja luovuuteen" ${ }^{10}$.

\footnotetext{
${ }^{1}$ https://upload.wikimedia.org/wikipedia/commons/thumb/0/0e/Lobes of the brain NL.svg/320pxLobes of the brain NL.svg.png

2 https://upload.wikimedia.org/wikipedia/commons/d/db/Hippocampus.png

3 https://upload.wikimedia.org/wikipedia/fi/6/6b/Geeni.png

${ }^{4}$ http://www.genecards.org/cgi-bin/carddisp.pl?gene=DRD4\&keywords=DRD4

5 http://www.tekniikkatalous.fi/tiede/kaukokaipuu-on-osittain-geneettista-elamyshakuiset-drd4-geenin-kantajatalttiimpia-matkustamaan-ja-muuttamaan-6308136

${ }^{6}$ http://www.tohtori.fi/?page=1616302\&id=1721726

7 https://www.researchgate.net/publication/259347411 Genetic etiology of eating disorders

8 http://www.genecards.org/cgi-bin/carddisp.pl?gene=MAOA\&keywords=MAOA

9 http://yle.fi/uutiset/3-7554385

${ }^{10}$ https://www.biomag.hus.fi/braincourse/L8.html\#RTFToC11
} 
Ihmisen kognitiivinen kapasiteetti on kuitenkin rajallinen, sillä ihminen voi esimerkiksi havainnoida vain 3-4 asiaa kerralla ja hän voi siirtää tarkkaavaisuuden kohteesta toiseen 2-3 kertaa sekunnissa [1]. Kognitiiviset palvelut (cognitive services) ja niitä hyödyntävät kognitiiviset sovellukset (cognitive apps) laajentavat ihmisten kognitiivista suorituskykyä tekoälyn eli kognitiivisen laskennan (cognitive computing) avulla. Kognitiivisia sovelluksia ja niiden muodostamisessa käytettyjä kognitiivisia palveluja on tutkittu sekä ei-vertaisarvioidun että vertaisarvioidun aineiston huomioonottavalla moniäänisellä kirjallisuuskatsauksella (multivocal literature review) [3]. Moniäänisessä kirjallisuuskatsauksessa [4] löydettiin kymmeniä kognitiivisia sovelluksia, joista sosiaali- ja terveydenhuollon sovelluksia olivat esimerkiksi mukaan SugarWise verensokeritasojen arvioimiseen ja Cataract Surgery App harmaakaihileikkauksen suunnitteluun ja toteuttamiseen sekä Seeing Al kertomaan näkövammaisille mitä ja ketä ympärillä on. Kognitiivisia sovelluksia on helpompi ymmärtää, kun ymmärtää niiden rakenneosien eli kognitiivisten palvelujen toiminnallisuuden.

Pauline von Bonsdorff ja Mikko Ylikangas kirjoittavat, että "tutkimus on parhaimmillaan, kun se ruokkii uutta tutkimusta, herättää uteliaisuutta ja uusintaa käytäntöjä" [5]. Tämän artikkelin tarkoitus on ensisijaisesti herättävät uteliasuutta kognitiivisten palvelujen tarjoamia mahdollisuuksia kohtaan. Esimerkiksi IBM Watson Personality Insights -palvelu, joka tekee tekstin pohjalta kirjoittajan persoonallisuuspiirretarkastelua, on yksi mielenkiintoisimmista [6]. Joidenkin piirteiden avulla voidaan sekä arvioida persoonallisuuden kypsyyttä että ennustaa ihmisen psyykkistä ja sosiaalista hyvinvointia "monet persoonallisuuden piirteet, jotka vaikuttavat elämänvalintoihin ja ennustavat huonoja ratkaisuja ja heikkoa elämänhallintaa, löytyvät samanlaisina sekä vanhemmilta että heidän lapsiltaan . . . vanhempi siirsi persoonallaan hyvin- tai pahoinvointia eteenpäin" [7].

Tässä artikkelissa tarkastellaan kognitiivisten palvelujen toiminnallisuutta kognitiivisten prosessien avulla, jotta opitaan arvioimaan ja hyödyntämään kognitiivisia palveluja ihmisen kognitiivisen suorituskyvyn kehittämisessä. Wang ja kumppanit ovat nimenneet ja osittain määritelleet 52 kognitiivista prosessia [8, 9], kun he ovat tutkineet kognitiivista laskentaa, jonka avulla matkitaan (mimick) aivomekanismeja liittyen esimerkiksi havainnointiin ja päättelyyn [10]. Google Scholar ja Scopushakutulokset eivät tuottaneet yhteen osumaa hakulausekkeella "cognitive service" AND "cognitive process". Koska emme löytäneet muita tutkimuksia kognitiivisten palvelujen ja kognitiivisten prosessien kohdentamisesta, niin tutkimuskysymyksemme muodostui se, mitä lisäarvoa saadaan, kun kohdennetaan kognitiiviset palveluja järjestelmällisesti kognitiivisiin prosesseihin. Kohdentamisen tavoitteeksi asetimme kognitiivisten palvelujen tuotosten hyödyntämisen selkeyttämisen ja sen, että muodostamme tarvittaessa kognitiivisten palvelujen tuotosten hyödyntämisen kohdentamismallin. Tutkimuksemme vaiheet ja niiden tulokset esitellään seuraavassa järjestyksessä:

1. Kokoamme kognitiivisille prosesseille määritelmät kahdesta aivojen viitemallia käsittelevästä artikkelista [8,9]. Luomme kohdentamissäännöt, joiden avulla kohdennamme kognitiivisia palveluja kognitiivisiin prosesseihin (Luku 2).

2. Kohdettaan 11 kognitiivista palvelua kohdentamissääntöjä hyödyntäen (Luku 3).

3. Koska kognitiivisten palvelujen kohdentamisen avulla halutaan selvittää myös sitä, miten kognitiivisten palvelujen tuotoksia voidaan hyödyntää, niin lopuksi konstruoidaan sellainen kohdentamistapa, joka tuo tietoisuuteen kognitiivisten palvelujen tarkoituksellisuuden kognitiivisten suorituskykyjen kehittämisessä (Luku 4).

\section{Aivojen viitemalli ja kohdentamissäännöt}

Kognitiivisiin prosesseihin liittyen Wang et al. [8] ovat muodostaneet aivojen viitemallin (the layered reference model of the brain, LRMB), jota Wang on täydentänyt [9]. Aivojen viitemallissa on 52 kognitiivista prosessia (Liite), jotka on ryhmitelty seitsemään mielen toimintoon (mental functions): aistiminen, toiminta, muisti, havainnointi, kognitio, päättely ja älykkyys. Kognitiivisille prosesseille [9] löytyy määritelmiä Wangin ja kumppaneiden artikkeleista [8,9]. Aivojen viitemallissa on sekä alitajuntaisia mielen toimintoja (aistiminen, 
toimiminen, muistaminen ja havainnoiminen) että tietoisia mielen toimintoja (kognitio, päättely ja älykkyys). Jotta kognitiivisista prosesseista tulee omakohtaisia, niin niiden nimet muutettiin aistiminen-, havainnointi-, kognitio- ja älykkyys-toimintoihin kuuluvien prosessien osalta käskymuotoisiksi (Kuva 2).
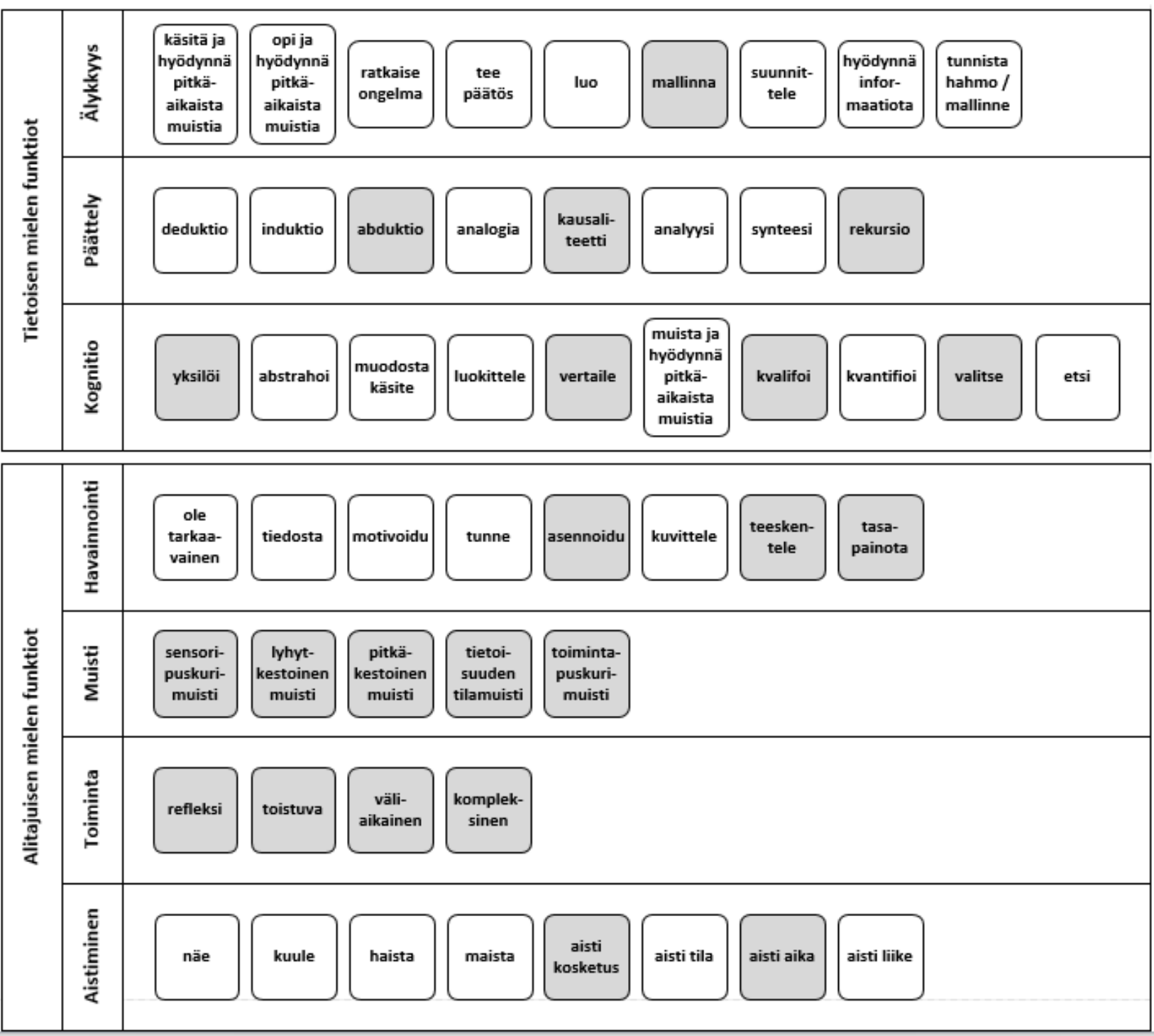

Kuva 2. Kognitiiviset prosessit, joista harmaita ei ole määritelty Wangin ja kumppaneiden [8] tai Wangin artikkelissa [9]. 

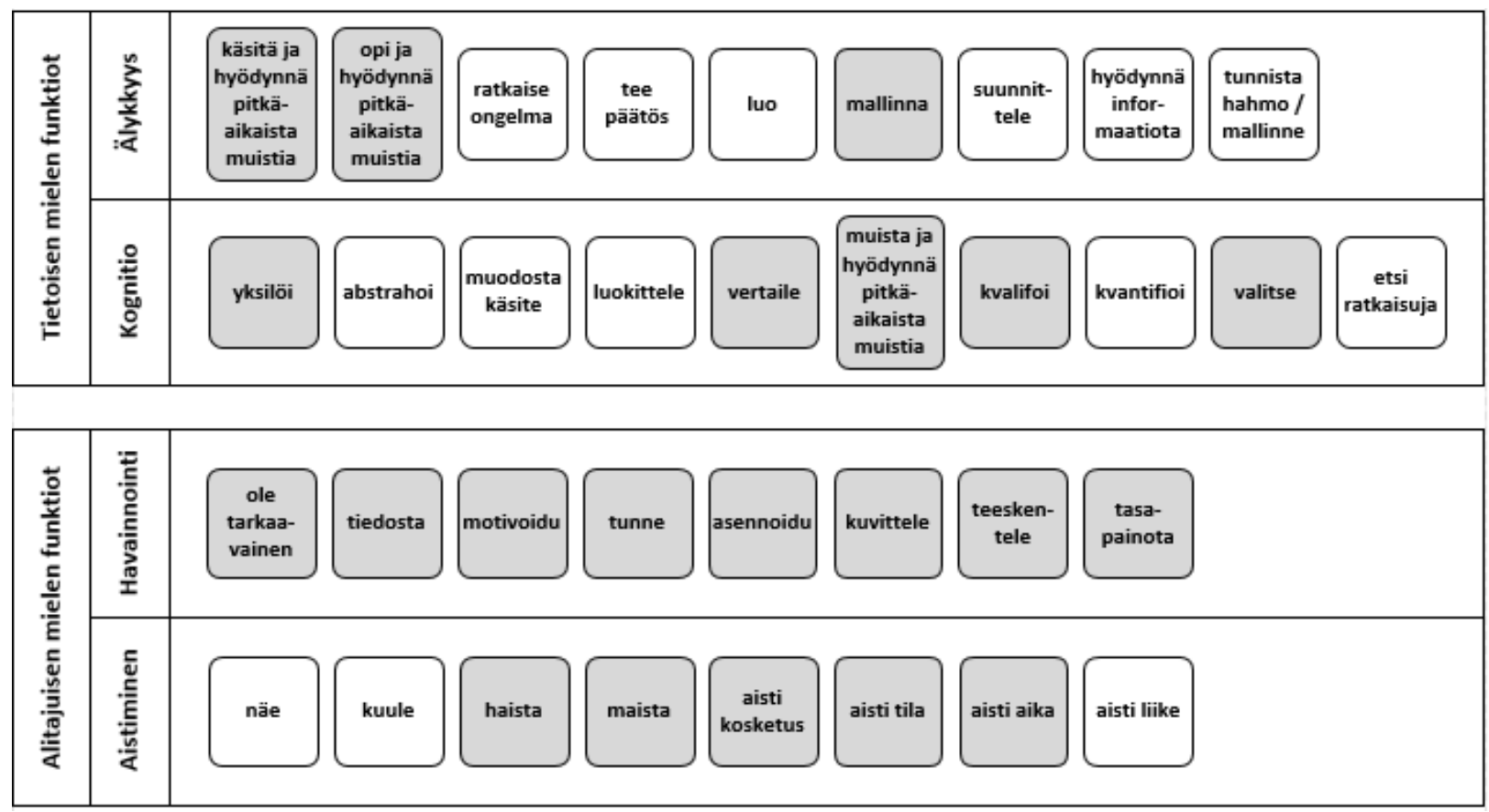

Kuva 3. Kohdentamissääntöjen muodostamisessa käytetyt kognitiiviset prosessit.

Kohdentamissääntöjen muodostamisessa käytettiin kognitiivisia prosesseja, jotka kuuluvat aistiminen-, kognitio- ja älykkyys-toimintoihin, sillä muisti- ja toiminta-prosesseja ei ole määritelty ja päättely-prosesseja ei voida kognitiivisten palvelujen kokeilun perusteella kohdentaa. Lisäksi kaikki havainnointi-prosessit jätettiin pois, sillä kognitiiviset palvelut tekevät havainnointiprosessit puolestamme ja tarjoavat kognitioprosesseihin tuotokset. Myös pitkäaikaista muistia hyödyntävät kognitiiviset palvelut jätettiin kohdentamisääntöjen ulkopuolelle. Lisäksi aistiminen-toiminnoista jäi pois haista-, maista- ja aisti tila -prosessit, sillä niihin ei löytynyt kohdennettavia kognitiivisia palveluja. Lisäksi denotaatioihin eli perusmerkityksiin katsotaan kuuluvaksi asenteet eli sentimentit, tunteet, lausekkeiden semanttiset roolit (subjekti, predikaatti eli action, objekti), entiteetit ja niiden attribuutit sekä entiteettien väliset suhteet ja niiden tyypit. Etsi-prosessi täydennettiin lisäämällä objektiksi ratkaisuja, sillä muutoin etsiprosessi assosioituu hakukoneisiin ja kyseessä on kuitenkin ratkaisuvaihtoehtojen etsiminen.

Perusajatuksena on, että jokainen kognitiivinen palvelu voidaan kohdentaa vähintään yhteen aistiminentoimintoon kuuluvaan prosessiin, yhteen kognitio- toimintoon ja yhteen älykkyys-toimintoon. Jollei jokaiseen toimintoon löydy prosessia, niin pyritään löytämään ainakin yksi alitajuntaan ja yksi tietoiseen mieleen kuuluva kognitiivinen prosessi, johon kognitiivinen palvelu kohdennetaan.

Kognitiivisille palveluille tehtiin seuraavat kohdentamiskriteerit, jotta ne voitiin kohdentaa aistiminen-, kognitio- ja älykkyys-toimintoihin kuuluviin kognitiivisiin prosesseihin seuraavilla perusteilla:

1. JOS kognitiivisen palvelun syöte on linkki, teksti tai tiedosto NIIN palvelu kohdennetaan näe-prosessiin

2. JOS kognitiivisen palvelun syöte sisältää ääntä NIIN palvelu kohdennetaan kuule-prosessiin

3. JOS kognitiivisen palvelun syöte on video NIIN palvelu kohdennetaan aisti liike -prosessiin

4. JOS kognitiivinen palvelun tuotoksessa on erilaisia denotaatioita NIIN palvelu kohdennetaan abstrahointi-prosessiin

5. JOS kognitiivinen palvelu tuotoksessa on käsitteitä (concepts) NIIN palvelu kohdennetaan muodosta käsite-prosessiin 
6. JOS kognitiivisen palvelun tuotoksessa on luokitteluja (classes) NIIN palvelu kohdennetaan luokittele-prosessiin

7. JOS kognitiivisessa palvelun tuotoksessa on arvioita (tuotoksessa esiintyy termi confidence tai relevance) ja/tai pisteytyksiä (scores) tuotosten luotettavuudesta NIIN palvelu kohdennetaan kvantifioi-prosessiin

8. JOS kognitiivinen palvelun syötesisällön perusteella ratkaisuvaihtoehtoja ongelmaan NIIN palvelu kohdennetaan etsi ratkaisuja -prosessiin

9. JOS kognitiivinen palvelu syöte on viallinen tai virheellinen JA palvelun tuotoksena viallisuus tai virheellisyys on korjattu NIIN palvelu kohdennetaan ratkaise ongelma -prosessiin

10. JOS kognitiivinen palvelu tuotoksena on jokin konkreettinen toiminto (kuten valojen sammuttaminen) NIIN palvelu kohdennetaan tee päätös -prosessiin

11. JOS kognitiivisen palvelun tuotoksena on syötesensitiivinen yhteenveto tai mu vastaava NIIN palvelu kohdennetaan luo-prosessiin

12. JOS kognitiivisen palvelun tuotoksessa on suosituksia NIIN palvelu kohdennetaan suunnittele-prosessiin

13. JOS kognitiivinen palvelu muuntaa informaation esitysmuotoa (kuten kääntää puhuttua tai kirjoitettua luonnollista kieltä) NIIN palvelu kohdennetaan hyödynnä informaatiota -prosessiin

14. JOS kognitiivinen palvelu tunnistaa syötteestä hahmon tai mallinteen, joka on syötesensitiivinen NIIN palvelu kohdennetaan tunnista mallinne -prosessiin

\section{Kognitiiviset palvelujen kohdentaminen}

IBM tarjoama sisältää 17 kognitiivista palvelua [11] ja Microsoftin 24 kognitiivista palvelua [12]. Molemmat palveluntarjoajat ovat ryhmitelleet ne samantapaisesti: kieli (language), puhe (speech), näkeminen (vision), näkemykset (IBM:n ryhmä data insights ja Microsoftin ryhmä knowledge) ja etsiminen (search, vain Microsoftilla). Tässä artikkelissa tarkastelemme sekä IBM:n että Microsoftin kognitiivisia palveluja, jotka on ryhmitelty toimittajien toimesta kieli-, puhe- tai näkeminenryhmiin. Molemmilta toimittajilta valittiin kustakin ryhmästä 1-3 palvelua, jotka havainnollistavat, kuinka palveluja kohdennetaan kohdennussääntöjen perusteella kognitiivisiin prosesseihin (Taulukko 1). Kuhunkin kohdennettuun palveluun on linkitetty sekä itse palvelun kokeilemiseen että sen dokumentaatioon liittyviä sivuja.

IBM Visual Recognition ${ }^{11}$ tunnistaa kuvan kasvoista iän ja sukupuolen sekä havaitsee kuvassa näkyviä asioita ja laskee tunnistuksille pisteytyksen. Microsoft Computer Vision API ${ }^{12}$ yksilöi kuvasta tunnisteita (tags), jotka perustuvat yli 2000 tunnistettavissa olevaan objektiin, elävään olentoon, maisemaan ja toimenpiteisiin (ecognizable objects, living beings, scenery, and actions), sekä ja arvioi tunnisteiden luotettavuuden. Ominaisuuksiltaan Microsoft Computer Vision API on monipuolisempi kuin IBM Visual Recognition, sillä se esimerkiksi tunnistaa, onko kuvassa aikuissisältöä ja onko kuva turhan rohkea (racy) sekä pisteyttää arviot. Jos kuvassa on kasvoja, niin silloin Microsoft Computer Vision API tunnistaa iän ja sukupuolen sekä pisteyttää arvionsa. Microsoft Computer Vision API tuottaa myös kuvasta sanallisen kuvauksen ja arvioi kuvauksen luotettavuutta sekä löytää ja kertoo kasvojen sijainnin. Vision-ryhmään kuuluvista kognitiivista palveluista valitsimme huteroita (shaky) videoita tasapainottavan Microsoft Video API ${ }^{13}$ palvelun. Lisäksi palvelu havaitsee ja seuraa videolla esiintyviä kasvoja sekä alueita, joilla havaitaan liikettä

\footnotetext{
${ }^{11}$ https://visual-recognition-demo.mybluemix.net/ 12 https://www.microsoft.com/cognitive-services/enus/computer-vision-api

${ }^{13}$ https://www.microsoft.com/cognitive-services/enus/video-api
} 
Taulukko 1. Kognitiiviset palvelut, syötteet ja tuotosesimerkit sekä kognitiiviset prosessit, joihin palvelut on kohdennettu, taulukossa MS=Microsoft ja TM=Tunnista mallinne.

\begin{tabular}{|c|c|c|c|c|c|}
\hline $\begin{array}{l}\text { Kognitiivinen } \\
\text { palvelu }\end{array}$ & Syöte & Tuotosesimerkkejä & $\begin{array}{l}\text { Aisti- } \\
\text { minen }\end{array}$ & Kognitio & Älykkyys \\
\hline $\begin{array}{l}\text { Vision - IBM } \\
\text { Visual Recogni- } \\
\text { tion }\end{array}$ & Kuva & $\begin{array}{l}\text { Luokat ja pisteet; Kasvo-ominaisuudet ja pisteet; Tyyp- } \\
\text { pihierarkiat }\end{array}$ & Näe & $\begin{array}{l}\text { Abstrahoi; } \\
\text { Kvantifioi; } \\
\text { Luokittele }\end{array}$ & TM \\
\hline $\begin{array}{l}\text { Vision - MS Com- } \\
\text { puter Vision } \mathrm{API}^{15}\end{array}$ & Kuva & $\begin{array}{l}\text { Kuvatunnusteet ja niiden luotettavuus (confidence); } \\
\text { Arvioi ja pisteyttää, onko kuvassa aikuissisältöä ja onko } \\
\text { kuva rohkea; Kiteyttää ja pisteyttää kuvan sisällön } \\
\text { tekstilausekkeella }\end{array}$ & Näe & $\begin{array}{l}\text { Abstrahoi; } \\
\text { Kvantifioi; } \\
\text { Luokittele }\end{array}$ & $\begin{array}{l}\text { TM; } \\
\text { Luo }\end{array}$ \\
\hline $\begin{array}{l}\text { Vision - MS Video } \\
\mathrm{API}^{16}\end{array}$ & Video & $\begin{array}{l}\text { Vakaa video; Tunnistetut kasvot ja niiden ajallinen } \\
\text { sijainti, Alueet, joilla havaitaan liikettä }\end{array}$ & $\begin{array}{l}\text { Näe; } \\
\text { Aisti } \\
\text { liike }\end{array}$ & & $\begin{array}{l}\text { Ratkaise } \\
\text { ongelma; } \\
\text { TM }\end{array}$ \\
\hline $\begin{array}{l}\text { Speech - MS } \\
\text { Speaker Recogni- } \\
\text { tion } \mathrm{API}^{17}\end{array}$ & Ääni & Puhujan tunnistaminen & Kuule & & TM \\
\hline $\begin{array}{l}\text { Speech - IBM } \\
\text { Speech to Text }\end{array}$ & Ääni & $\begin{array}{l}\text { Puheen sanojen tunnistaminen ja tunnistuksen pro- } \\
\text { sentuaalinen arvio sekä vaihtoehtoisten sanojen esit- } \\
\text { täminen }\end{array}$ & $\begin{array}{l}\text { Kuule; } \\
\text { Näe }\end{array}$ & $\begin{array}{l}\text { Abstrahoi; } \\
\text { Kvantifioi; } \\
\text { Luokittele }\end{array}$ & $\begin{array}{l}\text { Hyödynnä } \\
\text { infor- } \\
\text { maatiota }\end{array}$ \\
\hline $\begin{array}{l}\text { Language - IBM } \\
\text { Natural Language } \\
\text { Understanding }\end{array}$ & $\begin{array}{l}\text { Teksti } \\
\text { tai } \\
\text { URL }\end{array}$ & $\begin{array}{l}5 \text { tunnetta ja asenteet koko tekstin ja lausekkeiden } \\
\text { tasolla sekä pisteytykset (score); Avainsanat ja niiden } \\
\text { luotettavuudet (relevance); Semanttiset roolit; Käsit- } \\
\text { teet ja niiden pisteet (score); Entiteetit ja niiden tyypit } \\
\text { sekä pisteytykset (score) }\end{array}$ & Näe & $\begin{array}{l}\text { Abstrahoi; } \\
\text { Kvantifioi; } \\
\text { Luokittele; } \\
\text { Muodosta } \\
\text { käsite }\end{array}$ & $\begin{array}{l}\text { Tunnista } \\
\text { mallinne }\end{array}$ \\
\hline $\begin{array}{l}\text { Language - IBM } \\
\text { Tone Analyzer }\end{array}$ & Teksti & $\begin{array}{l}\text { Koko tekstin ja lauseiden tasolla prosenttiosuuksina } 5 \\
\text { tunnetta, } 3 \text { kirjoitustyyliä ja } 5 \text { sosiaalista taipumusta }\end{array}$ & Näe & $\begin{array}{l}\text { Abstrahoi; } \\
\text { Kvantifioi; } \\
\text { Luokittele }\end{array}$ & TM \\
\hline $\begin{array}{l}\text { Language - IBM } \\
\text { Personality In- } \\
\text { sights }^{21}\end{array}$ & Teksti & $\begin{array}{l}47 \text { persoonallisuuspiirrettä (tyypit, arvot ja tarpeet) ja } \\
\text { niiden prosentuaaliset osuudet (0-100 \%) sekä yhteen- } \\
\text { vedot; Kulutusmieltymykset }\end{array}$ & Näe & $\begin{array}{l}\text { Abstrahoi; } \\
\text { Kvantifioi; } \\
\text { Luokittele; } \\
\text { Etsi ratkaisuja }\end{array}$ & $\begin{array}{l}\text { TM; Luo; } \\
\text { Suunnit- } \\
\text { tele }\end{array}$ \\
\hline $\begin{array}{l}\text { Language - MS } \\
\text { Linguistic Analysis } \\
\mathrm{API}^{22}\end{array}$ & Virke & Virke konstituenttipuuksi & Näe & $\begin{array}{l}\text { Abstrahoi; } \\
\text { Luokittele }\end{array}$ & TM \\
\hline $\begin{array}{l}\text { Language - MS } \\
\text { Bing Spell Check } \\
\mathrm{API}^{23}\end{array}$ & Teksti & Korjattu teksti & Näe & & $\begin{array}{l}\text { TM; } \\
\text { Ratkaise } \\
\text { ongelma }\end{array}$ \\
\hline $\begin{array}{l}\text { Language - MS } \\
\text { Language Under- } \\
\text { standing Intelli- } \\
\text { gent Service }\end{array}$ & $\begin{array}{l}\text { Valin- } \\
\text { ta- } \\
\text { vaihto } \\
\text {-ehdot }\end{array}$ & Toimintosidonnainen (action binding) tulos & Näe & & $\begin{array}{l}\text { Tee } \\
\text { päätös }\end{array}$ \\
\hline
\end{tabular}

${ }^{14}$ https://www.ibm.com/watson/developercloud/doc/visual-recognition/index.html

${ }^{15}$ https://www.microsoft.com/cognitive-services/en-us/computer-vision-api/documentation

${ }_{16}^{16}$ https://www.microsoft.com/cognitive-services/en-us/video-api/documentation/home

${ }^{17}$ https://www.microsoft.com/cognitive-services/en-us/speaker-recognition-api/documentation

${ }_{18}^{18}$ https://www.ibm.com/watson/developercloud/doc/speech-to-text/index.html

${ }_{19} \mathrm{https://www.ibm.com/watson/developercloud/doc/natural-language-understanding/}$

${ }^{20}$ https://www.ibm.com/watson/developercloud/doc/tone-analyzer/index.html

${ }^{21}$ https://www.ibm.com/watson/developercloud/doc/personality-insights/index.html

${ }^{22}$ https://www.microsoft.com/cognitive-services/en-us/linguistic-analysis-api/documentation/overview

${ }^{23}$ https://www.microsoft.com/cognitive-services/en-us/bing-spell-check-api/documentation

${ }^{24}$ https://www.microsoft.com/cognitive-services/en-us/luis-api/documentation/home 
IBM Speech to Text ${ }^{25}$ kääntää puheen tekstiksi sekä löytää puheesta määritellyt avainsanat. Lisäksi palvelu havaitsee toisilleen vaihtoehtoiset sanat ja arvioi vaihtoehtoisten sanojen todennäköisyydet. Microsoft Speaker Recognition $\mathrm{API}^{26}$ tunnistaa puhujan äänen ja sen avulla voi opettaa palvelua tunnistamaan esimerkiksi oman äänen.

IBM Natural Language Understanding ${ }^{27}$ tunnistaa koko tekstistä tai tekstin yksittäisistä sanoista asenteen (positiivinen, negatiivinen, neutraali), tunteet (ilo, viha, disgust, surullisuus, pelko) ja semanttiset roolit (subjekti, verbi ja objekti). Lisäksi palvelu havaitsee entiteetit, kategoriat ja käsitteet sekä löytää tekstistä avainsanat. IBM Tone Analyzer ${ }^{28}$ tunnistaa dokumentin sävyn eli tunteet (viha, disgust, pelko, ilo ja surullisuus), kirjoitustyylin (analyyttinen, luottavainen, epävarma) ja sosiaaliset taipumukset (avoimuus, tietoisuus, ulospäinsuuntautuneisuus, myöntyvyys ja emotionaalinen vaihtelu) sekä arvioi sävyjä prosentuaalisesti. IBM Personality Insights $^{29}$ tunnistaa tekstistä kirjoittajan 47 persoonallisuuden ominaispiirrettä (Big Five -persoonallisuustyypit ja niihin kuuluvat 30 piirrettä, tarpeet ja niihin kuuluvat 12 piirrettä sekä arvot ja niihin luukuvat 5 piirrettä) ja arvioi piirteitä prosentuaalisesti. Lisäksi palvelu tuottaa sanallisen yhteenvedon henkilön persoonallisuudesta ja havaitsee sanallisesti, mistä tekstin kirjoittaja mahdollisesti pitää ja mistä ei.

Microsoft Linguistic Analysis $\mathrm{API}^{30}$ abstrahoi virkerakenteen konstituenttipuuksi (constituency tree) eli tunnistetaan esimerkiksi, kuka tekee mitäkin ja kenelle - palvelun jäsennystuloksen tulkinnassa tarvitaan ainakin alkuvaiheessa jäsennystulosten selostuksia ja ymmärrystä virkkeistä (sentences). Microsoft Bing Spell Check

${ }^{25}$ https://speech-to-text-demo.mybluemix.net/

26 https://www.microsoft.com/cognitive-services/enus/speaker-recognition-api

${ }^{27}$ https://natural-language-understandingdemo.mybluemix.net/

${ }^{28}$ https://tone-analyzer-demo.mybluemix.net/

29 https://personality-insights-livedemo.mybluemix.net/

30 https://www.microsoft.com/cognitive-services/enus/linguistic-analysis-api
$\mathrm{API}^{31}$ havaitsee kirjoitusvirheet sekä osaa käsitellä esimerkiksi homofoneja (homophones), jotka äännetään samalla tavalla, mutta ovat kirjoitusasultaan ja merkitykseltään erilaisia kuten Lucia ja lusia. Microsoft Language Understanding Intelligent Service ${ }^{32}$ tuottaa niin sanottuja toimintosidonnaisia tuloksia (action binding results) ymmärtämällä kieltä kontekstuaalisesti. Sovellus tai (ro)botti ymmärtää syötettyä tekstimuotoista luonnollista kieltä pystyen päättelemään lauseesta tarkoituksen (intent) ja muuntaa sen toiminnaksi kuten sytyttää ja sammuttaa lamppuja.

\section{Tuotosten hyödyntämisen kohdentamismalli}

Kognitiivisten palvelujen tuotosten hyödyntämistä tukeva kohdentamismalli rakentui kuuden kognitiivisen palvelun tuotosten perusteella (Kuva 4):

- IBM Natural Language Understanding auttaa fasilitoimaan denotaatioita ja denotaatioiksi katsotaan esimerkiksi entiteetit, lausekkeiden osat kuten semanttiset roolit

- IBM Personality Insights tuomaan tietoisuuteen (eli manifestoi) käyttäytymispiirteitä ja kulutusmieltymyksiä

- IBM Tone Analyzer mahdollistaa tekstin tarkastamisen ja korjaamisen (eli revisoi) osoittamalla tekstistä kirjoitustyylejä. Palvelu myös manifestoi sosiaalisia taipumuksia ja auttaa fasilitoimaan tunteita

- Microsoft Language Understanding Intelligent Service auttaa toimintosidonnaisten tulosten muodostamisessa (eli bindaa) kuten esimerkissä olevan huoneiston valaistukseen vaikuttamisen

- Microsoft Computer Vision API auttaa sekä fasilitoinnissa ja kuvien korjaamisessa (eli revisoi) moderoinnin lisäksi

- Microsoft Linguistic Analysis API on auttaa lausekkeiden fasilitoinnissa tuottamansa konstituenttipuun vuoksi.

\footnotetext{
${ }^{31}$ https://www.microsoft.com/cognitive-services/enus/bing-spell-check-api

32 https://www.microsoft.com/cognitive-services/enus/language-understanding-intelligent-service-luis
} 


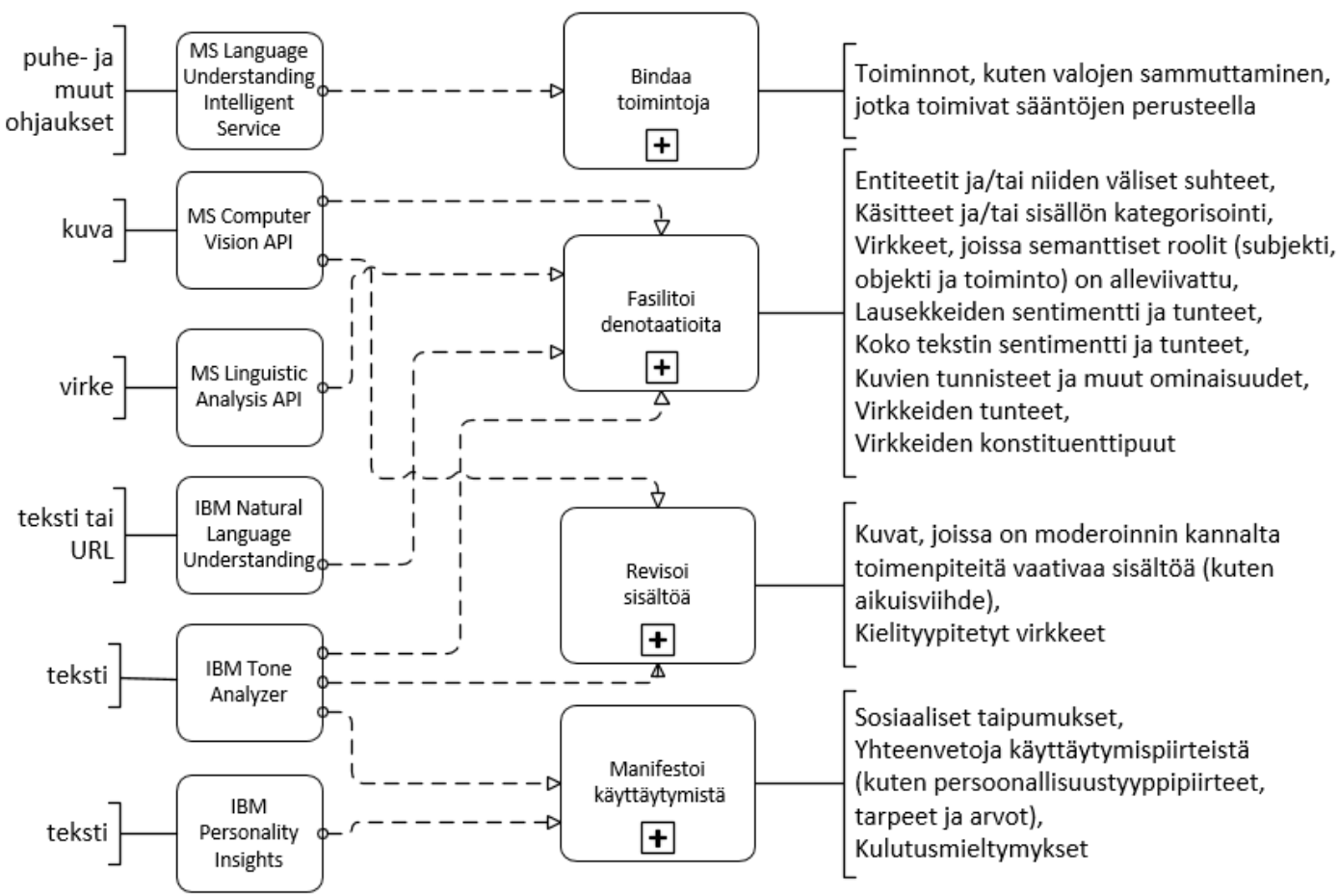

Kuva 1. Esimerkkejä kognitiivisten palvelujen tuottamien tuotosten jatkohyödyntämisestä.

Koska kohdentamiskonstruktio on uusi, niin pyrittiin luomaan sellainen kohdentamistapa, joka tuo tietoisuuteen kognitiivisten palvelujen kognitiivista suorituskykyä edesauttavia ominaisuuksia. Kun kognitiivisten palvelujen tuotoksia tarkastellaan, niin niiden perusteella muodostetaan neljä toiminnallisuutta (bindaa, fasilitoi, revisoi, manifestoi), jotka kuvaavat tuotosten tarjoamia toiminnallisuus-mahdollisuuksia:

- Bindaa esiintyy Microsoft Language Understanding Intelligent Service -kuvauksessa, kun kerrotaan toimintosidonnaisista tuloksista (action binding results). Kognitiiviset prosessit tee päätös ja ratkaise ongelma voivat viitata toimintojen bindaamiseen.

- Fasilitoinnilla viitataan toiminnan helpottamiseen ja se kuvaa hyvin denotaatioiden hyödyntämistavoitteita. Jollei tuotosta perustellusti kohdenneta kolmeen muuhun verbiin, niin oletusarvoisesti se kuuluu fasilitointiin.
- Revisoi esiintyy IBM Tone Analyzer kuvauksessa yhtenä verbinä ja kuvaa hyvin esimerkiksi tekstin muokkaamista kognitiivisten palvelujen avulla sisällöltään sopivaksi. Jotta revisointia voidaan tehdä, niin se edellyttää, että revisoitavia asioita, kuten kirjoitustyyliä, voidaan tarkastella esimerkiksi virketasolla.

- Manifestoi on kuvaava verbi, etenkin, kun tarkastellaan piirteitä, joita ihmisen on jopa mahdoton havaita, puhumattakaan piirteiden perusteella tehtävistä suosituksista ja muista vastaavista yhteenvedoista. Kognitiivinen prosessi suunnittele voi viitata käyttäytymisen manifestoitumiseen.

Kun kognitiivisten palvelujen tuotoksia tarkastellaan aluksi fasilitoinnin näkökulmasta, niin tuotoksille voidaan keksiä esimerkiksi revisointikäyttöä. Virkkeitä voidaan uudelleen kirjoittaa tyylillisesti tai muuttamalla keskeisten lauseenjäsenien roolia. Manifestoidut asiat, kuten persoonallisuuspiirteet, voivat aiheuttaa aluksi 
jopa pelkoa tai vastenmielisyyttä. Toisaalta manifestointia tekevät kognitiiviset palvelut ovat niitä, jotka osoittavat meille ihmisille oman suorituskykymme rajallisuuden ja herättelevät kiinnostusta kognitiivisia palveluja kohtaan.

Verbeinä bindaa, fasilitoi, revisoi ja manifestoi ovat huomiota herättäviä ja niillä haluttiin korostaa kognitii- visten palvelujen erityispiirteitä. Verbeistä ainoastaan fasilitoi on vakiintunut puhekieleen, mutta bindaamisen tuntenevat ohjelmoijat, revisoinnin englannin kielistä tekstinkäsittelyohjelmaa hyödyntävät ja manifestoida tulee esille, kun käsitellään tietoisuuteen liittyviä asioita.

Taulukko 2. Kognitiiviset palvelut, syötteet ja tuotosesimerkit sekä kognitiiviset prosessit, joihin palvelut on kohdennettu, taulukossa MS=Microsoft ja TM=Tunnista mallinne.

\begin{tabular}{|c|c|c|c|c|}
\hline Kognitiivinen palvelu & $\begin{array}{l}\text { Bindaa } \\
\text { toimintoja }\end{array}$ & Fasilitoi denotaatioita & Revisoi sisältöä & $\begin{array}{l}\text { Manifestoi käyttäyty- } \\
\text { mistä }\end{array}$ \\
\hline $\begin{array}{l}\text { Vision - IBM Visual } \\
\text { Recognition }\end{array}$ & & $\begin{array}{l}\text { Luokat ja pisteet; Kasvo- } \\
\text { ominaisuudet ja pisteet; Tyyp- } \\
\text { pihierarkiat }\end{array}$ & & \\
\hline $\begin{array}{l}\text { Vision - MS Computer } \\
\text { Vision API }\end{array}$ & & $\begin{array}{l}\text { Kuvatunnusteet ja niiden luotet- } \\
\text { tavuus; Kiteyttää ja pisteyttää } \\
\text { kuvan sisällön tekstilausekkeella }\end{array}$ & $\begin{array}{l}\text { Arvioi ja pisteyttää, } \\
\text { onko kuvassa } \\
\text { aikuissisältöä ja } \\
\text { onko kuva rohkea }\end{array}$ & \\
\hline Vision - MS Video API & Vakaa video & $\begin{array}{l}\text { Tunnistetut kasvot ja niiden } \\
\text { ajallinen sijainti, Alueet, joilla } \\
\text { havaitaan liikettä }\end{array}$ & & \\
\hline $\begin{array}{l}\text { Speech - MS Speaker } \\
\text { Recognition API }\end{array}$ & & Puhujan tunnistaminen & & \\
\hline $\begin{array}{l}\text { Speech - IBM Speech to } \\
\text { Text }\end{array}$ & & $\begin{array}{l}\text { Puheen sanojen tunnistaminen } \\
\text { ja tunnistuksen prosentuaalinen } \\
\text { arvio }\end{array}$ & $\begin{array}{l}\text { Puheen vaihtoeh- } \\
\text { toisten sanojen } \\
\text { esittäminen }\end{array}$ & \\
\hline $\begin{array}{l}\text { Language - IBM Natural } \\
\text { Language Understand- } \\
\text { ing }\end{array}$ & & $\begin{array}{l}5 \text { tunnetta ja asenteet koko } \\
\text { tekstin ja lausekkeiden tasolla } \\
\text { sekä pisteytykset; Avainsanat ja } \\
\text { niiden luotettavuudet; Käsitteet } \\
\text { ja niiden pisteet; Entiteetit ja } \\
\text { niiden tyypit sekä pisteytykset }\end{array}$ & Semanttiset roolit & \\
\hline $\begin{array}{l}\text { Language - IBM Tone } \\
\text { Analyzer }\end{array}$ & & $\begin{array}{l}\text { Koko tekstin ja virkkeiden tasol- } \\
\text { la prosenttiosuuksina } 5 \text { tunnetta }\end{array}$ & $\begin{array}{l}\text { Virkkeiden tasolla } \\
\text { prosenttiosuuksina } \\
3 \text { kirjoitustyyliä }\end{array}$ & $\begin{array}{l}\text { Koko testin ja virkkei- } \\
\text { den tasolla prosent- } \\
\text { tiosuuksina } 5 \text { sosiaalis- } \\
\text { ta taipumusta }\end{array}$ \\
\hline $\begin{array}{l}\text { Language - IBM Per- } \\
\text { sonality Insights }\end{array}$ & & & & $\begin{array}{l}47 \text { persoonallisuus- } \\
\text { piirrettä (tyypit, arvot } \\
\text { ja tarpeet) ja niiden } \\
\text { prosentuaaliset osuu- } \\
\text { det ( } 0-100 \% \text { ) sekä } \\
\text { yhteenvedot; } \\
\text { Kulutusmieltymykset }\end{array}$ \\
\hline $\begin{array}{l}\text { Language - MS Linguis- } \\
\text { tic Analysis API } \\
\text { Language - MS Bing } \\
\text { Spell Check API }\end{array}$ & Korjattu teksti & Virke konstituenttipuuksi & & \\
\hline $\begin{array}{l}\text { Language - MS Lan- } \\
\text { guage Understanding } \\
\text { Intelligent Service }\end{array}$ & $\begin{array}{l}\text { Toiminto- } \\
\text { sidonnainen } \\
\text { (action bind- } \\
\text { ing) tulos }\end{array}$ & & & \\
\hline
\end{tabular}




\section{Johtopäätökset ja pohdinta}

Kun kysyttiin, mitä lisäarvoa saadaan, kun kohdennetaan kognitiiviset palveluja järjestelmällisesti kognitiivisiin prosesseihin, niin lisäarvoa syntyi siitä, että kognitiivisten palvelujen tuotoksia piti tarkastella mahdollimahdollisimman yksityiskohtaisesti, jotta palvelu voitiin kohdentaa kognitio- ja älykkyysprosesseihin. Lisäarvoa ei juurikaan syntynyt itse kohdentamistuloksesta, vaan kohdentamisen perusteista eli kohdentamisäännöistä ja mahdollisimman tarkasti määritellyistä tuotoksista. Lisäksi tuotosten yksityiskohtainen tarkastelu pakotti miettimään käyttötapauksia, joissa tuotoksia voi hyödyntää jopa itsenäisesti. Kohdentamisen aikana kognitiivisten palvelujen hyödyntäminen selkeytyi, mikä mahdollisti kognitiivisten palvelujen tuotosten hyödyntämisen kohdentamismallin konstruoinnin. Kun tarkastellaan tulosten luotettavuutta ja oikeellisuutta, niin on huomioitava, että kohdentaminen tehtiin parityönä ja sekä kohdentamisäännöstöistä ja kohdennuksista eli olemassa useita eri versioita tutkimuksen aikana. Kun säännöt päätettiin kirjoittaa siten, että ne sidostaan selkeästi palvelusyötteisiin ja -tuotoksiin, niin kohdentamistuloksista päästiin yksimieleisyyteen.

Teoreettinen malli voi olla "käyttökelpoinen uusien teorioiden kehittämisessä ja vanhojen teorioiden ymmärtämisessä ja laajentamisessa" [13]. Koska Wangin ja kumppaneiden esittämä aivojen viitemalli ovat osittain määriteltyjä teoreettinen malli, niin se ei toimi sellaisenaan esimerkiksi uusien teorioiden kehittämisessä. Wangin ja kumppaneiden aivojen viitemalli määrittelee kognitiivisuuden, tai paremminkin mielen toiminnallisuuden, tarkemmin kuin esimerkiksi "mieli voidaan nähdä ryväksenä toimintoja, jotka kehittyvät ja muovautuvat ihmisen ja hänen ympäristönsä välisessä jatkuvassa vuorovaikutuksessa" [5]. Wangin ja kumppaneiden määrittelemät kognitiiviset prosessit auttavat arvioimaan kognitiivisia palveluja tarkemmin kuin esimerkiksi toimittajien eli IBM:n ja Microsoftin tekemät ryhmittelyt. Lisäksi, kun uusia kognitiivisia palveluja kehitetään, niiden käyttötarkoitusta voidaan havainnollistaa kognitiivisten prosessien avulla. Aivojen viitemalli pakottaa miettimään kognitiivisia prosesseja ja tässä tutkimuksessa viitemalli antoi pohjan kognitiivisten palvelujen kohdentamismallille.
Kognitiivinen laskenta ja siihen liittyen kognitiiviset palvelut ja sovellukset kehittyvät todella nopeasti pelkästään vertaisarvioitujen julkaisujen seuraaminen ei riitä, vaan pitää seurata moniäänistä kirjallisuuskatsausta mukaillen kaikkien ammattilaisten näkemyksiä ja ottaa selkoa esimerkiksi uutisoinnista. Uutisoinnissa raportoidaan usein IBM Watsonin tietämyskannasta, jota pidetään tekoälyn ilmentymänä ja jota asiantuntijat, kuten lääkärit, käyttävät työssään, kun he etsivät todistepohjaisia vastauksia kysymyksiinsä. Tietämyskannasta asiantuntijat voivat poimia näkemyksiä omien päätöstensä perusteluiksi. Tietämyskanta ei ole muodostunut ainoastaan tekoälyn avulla, vaan sen muodostamisessa ja sen sisällön oikeellisuuden varmistamisessa käytetään asiantuntijoita tekemään interventioita. Tässä tutkimuksessa keskityimme tietämyskannan hyödyntämisen sijaan tarkastelemaan yksittäisiä rakenneosia eli kognitiivisia palveluja, joiden avulla voidaan muodostaa kognitiivisia sovelluksia eri tarkoituksiin.

\section{Lähteet}

[1] Palva S, Palva M. Mielentilojen vaihtelut ja tietoisuuden rajat. Mielen salat, Suomen Akatemia ja Gaudeamus. 2016;129-139.

[2] Baddeley A, Eysenck MW, Anderson MC. Memory. Second edition. Psychology Press; 2015.

[3] Ogawa RT, Malen B. Towards rigor in reviews of multivocal literatures: Applying the exploratory case study method. Review of Educational Research, 1991;61(3):265-286.

https://doi.org/10.3102/00346543061003265

[4] Lauronen H. Kognitiiviset sovellukset - moniääninen kirjallisuuskatsaus. Itä-Suomen yliopisto; 2017.

[5] von Bonsdorff P, Ylikangas M. Esipuhe. Mielen salat, Suomen Akatemia. 2016;7-13.

[6] Hotti V, Gain U. Exploitation and exploration underpin business and insights underpin business analytics. 6th International Conference on Well-Being in the Information Society. 2016, p. 223-37. 
[7] Keltinkangas-Järvinen L. Mielen merkitys hyvin- ja pahoinvoinnin siirtymässä. Mielen salat, Suomen Akatemia. 2016; 82-93.

[8] Wang Y, Wang Y, Patel S, Patel D. A layered reference model of the brain (LRMB). IEEE Transactions on Systems, Man, and Cybernetics, Part C (Applications and Reviews). 2006;36(2):124-133. https://doi.org/10.1109/TSMCC.2006.871126

[9] Wang Y. Formal Cognitive Models of Data, Information, Knowledge, and Intelligence. WSEAS Transactions on Computers. 2015;14:770-81.

[10] Wang Y, Rolls ET, Howard N, Shell DF. Cognitive Informatics: From Information Revolution to Intelli- gence Revolution, International Journal of Software Science and Computational Intelligence. 2015;7(2):5271. https://doi.org/10.4018/IJSSCI.2015040103

[11] IBM. Watson Services [Internet, viitattu 10.2.1017]. Saatavilla http://www.ibm.com/watson/

developercloud/services-catalog.html

[12] Microsoft. Discover the APIs [Internet, viitattu 10.1.2017]. Saatavilla https://www.microsoft.com/ cognitive-services/en-us/apis

[13] Haaparanta L, Niiniluoto I. Johdatus tieteelliseen ajatteluun. Gaudeamus, 2016. 
Liite 1. Kognitiivisten prosessien määritelmät.

Prosessien englannin kieliset nimet ovat Wangin (2015) artikkelista ja määritelmät pääasiassa Wnag et al. (2006) artikkelista. Jollei prosessiin ole lisätty englannin kielistä määritelmää, niin sitä ei ole Wangin ja kumppaneiden artikkeleista löytynyt.

Aistiminen (sensation) sisältää seuraavat kahdeksan prosessia:

- Näkeminen (vision) - "Detects and receives visual information from the entities of the external world in the forms of images, shapes, sizes, colors, and other attributes or characteristics" (Wang et al., 2006)

- Kuuleminen (hearing) - "Audition ... detects and receives aural information from sources of the external world in the forms of intensity, frequency, location, and other attributes and characteristics" (Wang et al., 2006)

- Liikkuminen (motion) - "Sense of motion . . . detects and interprets status changes related to space and time of external objects or the observer himself in real time" (Wang et al., 2006)

- Haistaminen (smell) - "Detects and receives scent by the olfactory nerves from sources of the external world" (Wang et al., 2006)

- Koskettaminen (touch) - "Tactility ... detects and receives touching information by the contact between an external object and a part of the body surface in the forms of heat, pressure, weight, pain and texture" (Wang et al., 2006)

- Maistaminen (taste) - "Detects and receives flavor information . . . via the taste buds from sources of the external world" (Wang et al., 2006)

- Tilan aistiminen (spaciality)

- Ajan aistiminen (time)

Havainnointi (perception) sisältää seuraavat kahdeksan prosessia:

- Tarkkaavaisuus (attention) - "Focuses the mind, or the perceptive thinking engine, on one of the objects or threads of thought by the selective concentration of consciousness" (Wang et al., 2006)

- Tiedostaminen (consciousness) - "Self-consciousness . . . maintains a stable mental state of human beings for sensation, perception, occurrent thought, and actions to function properly" (Wang et al., 2006)

- Motivoituminen (motivation) - "Explains the initiation, persistence, and intensity of CPs [cognitive processes]" (Wang et al., 2006)

- Tunteminen (emotion) - "Emotions are a set of states or results of perception that interpret the feelings of human beings on external stimuli or events in the categories of pleasant or unpleasant, such as joy/worry, happiness/sadness, safety/fear, and pleasure/angry" (Wang et al., 2006)

- Kuvitteleminen (imagination) - "Imagery . . . abstractly sees acquired visual images stored in the brain without any sensory input, or establish a relation between a mental image and the corresponding external entities or events" (Wang et al., 2006)

- Asennoituminen (attitude)

- Teeskenteleminen (posture)

- Tasapainottaminen (equilibrium)

Kognitio (cognition) sisältää seuraavat 10 prosessia:

- Abstrahointi (abstraction) - "Elicit a target subset of objects in a given discourse that shares a common property as an identity of the subset from the whole in order to facilitate denotation and reasoning" (Wang, 2015) 
- Käsitteellistäminen (concept establishment) - “Constructs a "to be" relation between an object or its attributes and existing objects / attributes" (Wang et al., 2006)

- Luokitteleminen (categorization) - "Identifies common and equivalent attributes or properties shared among a group of entities or objects and then uses the common attributes or properties to identify this group of entities" (Wang et al., 2006)

- Muistaminen (memorization) - "Encodes, stores, and retrieves information in LTM, partially controlled by the subconscious processes of sensation, memory, and perception" (Wang et al., 2006)

- Kvantifiointi (quantification) - "Measures and specifies the quantity of an object or attribute by using a quantifier such as all, some, most, and none, or by using a more exact rational measurement scale" (Wang et al., 2006)

- Etsiminen (search) - "Based on trial-and-error explorations to find a set of correlated objects, attributes, or relations for a given object or concept; or to find useful solutions for a given problem" (Wang et al., 2006)

- Yksilöiminen (the identification of the objects)

- Vertaileminen (comparison)

- Kvalifiointi (qualification)

- Valitseminen (selection)

Päättely (inference) sisältää seuraavat kahdeksan prosessia:

- Deduktio (deduction) - "By which a specific conclusion necessarily follows from a set of general premises" (Wang et al., 2006)

- Induktio (induction) - "By which a general conclusion is drawn from a set of specific premises based mainly on experience or experimental evidences" (Wang et al., 2006)

- Analogia (analogy) - "Identifies similarity of the same relations between different domains or systems and/or examines that if two things agree in certain respects then they probably agree in others" (Wang et al., 2006)

- Analyysi (analysis) - "Divides a physical or abstract object into its constitute parts in order to examine or determine their relationship deductively" (Wang et al., 2006)

- Synteesi (synthesis) - "Combines objects or concepts into a complex whole inductively" (Wang et al., 2006)

- Abduktio (abduction)

- Kausaliteetti (causation)

- Rekursio (recursion)

Älykkyys (intelligence) sisältää seuraavat yhdeksän prosessia:

- Käsittäminen (comprehension) - "Searches relations between a given object $(O)$ or attribute $(A)$ and other objects, attributes, and relations (R) in LTM, and establishes a representative OAR model for the object or attribute by connecting it to the appropriate clusters of the LTM" (Wang et al., 2006)

- Oppiminen (learning) - "Gains knowledge of something or acquires skills in some action or practice by updating the cognitive models of the brain in LTM" (Wang et al., 2006)

- Ongelman ratkaiseminen (problem solving) - "Searches a solution for a given problem or finds a path to reach a given goal" (Wang et al., 2006)

- Päätöksen tekeminen (decision making) - "By which a preferred option or course of action is chosen from among a set of alternatives on the basis of given criteria" (Wang et al., 2006) 
- Luominen (creation) - "Discovers a new relation between objects, attributes, concepts, phenomena, and events, which is original, proven true, and useful" (Wang et al., 2006)

- Suunnitteleminen (planning) - "Generates abstract representations of future actions, statuses, or paths to achieving a given goal, based on current information" (Wang et al., 2006)

- Informaation hyödyntäminen (information fusion) - "Knowledge representation ... describes how information can be appropriately encoded and utilized in the cognitive models of the brain" (Wang et al., 2006)

- Hahmon/mallinteen tunnistaminen (pattern recognition) - "Recognition . . . identifies an object by relating it to a concept or category, or comprehends a concept by known meanings" (Wang et al., 2006)

- Mallintaminen (modeling)

Toiminta (action) sisältää seuraavat neljä prosessia: refleksi (reflex), toistuva (recurrent) väliaikainen (temporary) ja kompleksinen (complex). Muisti (memory) sisältää seuraavat viisi prosessia: pitkäkestoinen muisti (long-term memory, LTM), lyhytkestoinen muisti (short-term memory, STM), sensoripuskurimuisti (sensory buffer memory, SBM), toimintapuskurimuisti (action buffer memory, ABM) ja tietoisuuden tilamuisti (conscious status memory, CSM). 